\title{
Contribution to the knowledge of pestalotioid fungi of Iran
}

\section{Arzanlou $\mathbf{M}^{1^{*}}$, Torbati $\mathbf{M}^{2}$, Khodaei $\mathbf{S}^{3}$, and Bakhshi $\mathbf{M}^{3}$} ${ }^{1}$ Assistant Professor of Plant Pathology and Mycology, Plant Protection Department, Faculty of Agriculture, University
of Tabriz, PO Box: 5166614766, Iran.
${ }^{2}$ MSc Student of Plant Pathology, Plant Protection Department, Faculty of Agriculture, University of Tabriz, PO Box:
5166614766, Iran.
${ }^{3}$ PhD Student of Plant Pathology (Mycology), Plant Protection Department, Faculty of Agriculture, University of
Tabriz, PO Box: 5166614766, Iran.

Arzanlou M, Torbati M, Khodaei S, Bakhshi M 2012 - Contribution to the knowledge of pestalotioid fungi of Iran. Mycosphere 3(5), 871-878, Doi 10.5943/mycosphere/3/5/12

Pestalotioid fungi, generally comprising Bartalinia, Monochaetia, Pestalotia, Pestalotiopsis, Sarcostroma, Seimatosporium, Truncatella, are coelomycetous genera with saprobic, endophytic or plant pathogenic life styles residing in the Amphisphaeriaceae (Xylariales). Little is known about the biodiversity of pestalotioid fungi in Iran. We provide a literature-based checklist for the pestalotioid fungi known to occur on different plant species in Iran. Two species, Bartalinia pondoensis and Pestalotiopsis neglecta are characterised based on morphological and molecular data from bamboo and rock samples, respectively. This is the first record of the genus Bartalinia from Iran and first report on the occurrence of $B$. pondoensis on bamboo and first report of $P$. neglecta on rock sample worldwide.

Key words - appendage - coelomycetes - Pestalotiopsis - Seimatosporium

\section{Article Information}

Received 18 September 2012

Accepted 21 September 2012

Published online 16 October 2012

*Corresponding author: Mahdi Arzanlou - e-mail - Arzanlou @ hotmail.com

\section{Introduction}

Pestalotioid fungi are anamorphic forms in the family Amphisphaeriaceae (Xylariales), which are characterized by appendage-bearing conidia (coelomycetes) (Barr 1975, 1990, Kang et al. 1998, 1999) and encompass several genera viz. Bartalinia Tassi, Ciliochorella Sydow, Discosia Libert, Monochaetia (Saccardo) Allescher, Monochaetiopsis Jeewon \& K.D. Hyde, Pestalotia De Notaris, Pestalotiopsis Steyaert, Sarcostroma Cooke, Seimatosporium Corda, Seiridium and Truncatella Steyaert (Tanaka et al. 2011). Members of these genera possess diverse life styles ranging from pathogens on plant species
(Espinoza et al. 2008, Tanaka et al. 2011, Arzanlou et al. 2012), endophytes or with both endophytic and pathogenic stages in their life cycle (Wei et al. 2005, 2007, Liu et al. 2006, Tejesvi et al. 2009, Watanabe et al. 2010), saprobes (Liu et al. 2008), or rarely causing diseases in humans (Sutton 1999, De Hoog et al. 2000).

For most pestalotioid genera the teleomorph remains unknown and taxonomy mainly relies on morphological criteria of conidia. The most important features for generic delineation include conidium septation (number of septa), lack or presence / shape and 

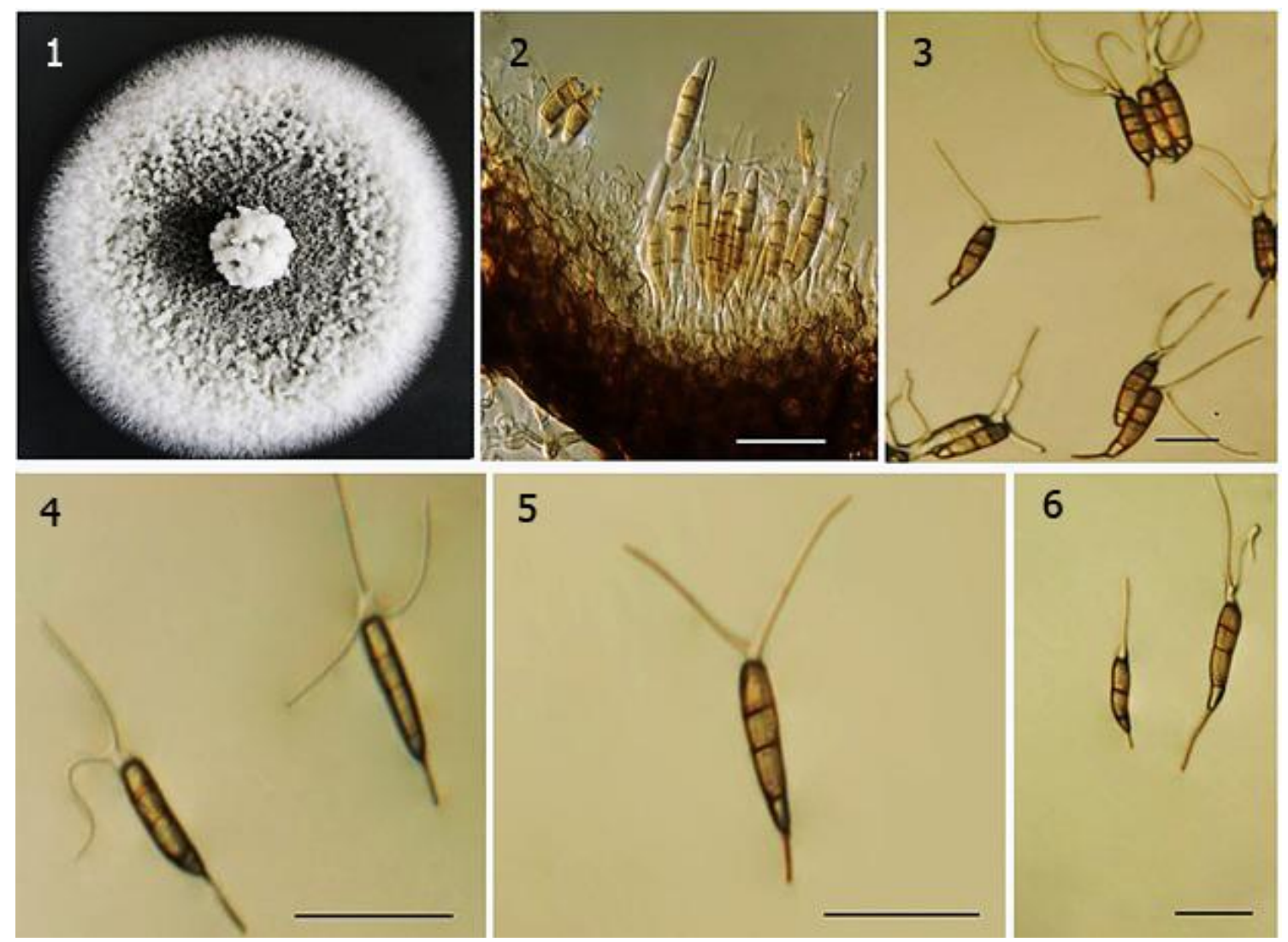

Figs 1-6 - Bartalinia pondoensis. 1 Colony morphology on PDA. 2 Conidia and conidiogenous cells. 3-6 Conidia. - Scale bars $(3,6=20 \mu \mathrm{m}, 4-5=10 \mu \mathrm{m})$.

branching pattern of appendages, pigmentation of median cell (Jeewon et al. 2002, 2003, 2004, Kang et al. 1998, 1999, Barber et al. 2011). However, the morphological criteria used for the delineation of pestalotioid fungi are insufficient and overlap among different genera (Lee et al. 2006, Barber et al. 2011). With the aid of DNA sequence data, taxonomy of pestalotioid fungi has undergone drastic revision (Jeewon et al. 2002, 2003, 2004, Kang et al. 1998, 1999, Lee et al. 2006) and now the boundaries of the genera are more clear (Lee et al. 2006, Tanaka et al. 2011).

Little is known on the biodiversity of pestalotioid fungi of Iran. With this paper we provide a check list for the already known pestalotioid fungi from Iran and characterize two pestalotioid species from Iran based on morphological and molecular data, which represent new records for Iran.

\section{Materials and Methods}

\section{List of species}

The list of pestalotioid fungi was compiled using reports available in the literature. Most of the quoted works are the result of field research by Iranian mycologists, although a small number of reports have been documented by foreign investigators. The list in Table 1 includes pestalotioid species together with their host species from which they have been collected. The fungal nomenclature and taxonomy follows Index Fungorum (http://www.indexfungorum.org/names/names.asp) and MycoBank (http://www.mycobank.org/).

Additional fungal isolates were recovered from apparently healthy bamboo stems, and rock sample during 2010. Isolation was made from bamboo stems following routine plant pathology methods. For the rock sample, isolation was made using soil dilution technique on $2 \%$ malt extract agar (MEA, Fulka, Hamburg, Germany), supplemented with $2 \mathrm{ml}$ of $20 \%$ lactic acid/liter. Single-spore cultures were deposited in the Culture Collection of Tabriz University (CCTU). Colony morphology including colour, shape, and growth rate was determined after 2 weeks of incubation on PDA at $25{ }^{\circ} \mathrm{C}$ in darkness. Squash mounts and handmade sections 
Table 1 Pestalotioid fungi known from Iran.

\begin{tabular}{|c|c|c|}
\hline Species & Hosts & References \\
\hline \multicolumn{3}{|l|}{ Monochaetia } \\
\hline $\begin{array}{l}\text { - crataegi (Ellis \& Everh.) Sacc. } \\
\text { \& D. Sacc. }\end{array}$ & Crataegus sp. & Ershad 1995 \\
\hline - concentrica (Berk. \& Broome) & Cydonia oblonga Mill. & Ershad 1995 \\
\hline \multicolumn{3}{|l|}{ Sacc. \& D. Sacc. } \\
\hline - karstenni (Sacc. \& Syd.) Sutton & Camellia sp. & $\begin{array}{l}\text { Fatehi \& Mirhosseini-Moghadam } \\
1993\end{array}$ \\
\hline Pestalotiopsis & Citrus aurantium L., C. limettoides & Roohibakhsh \& Ershad 1997 \\
\hline $\begin{array}{l}\text {-citri (Mundk. \& Khesw.) Ershad } \\
\text { \& Roohib. }\end{array}$ & Tanaka, C. unshiu Marcow & \\
\hline \multirow[t]{5}{*}{-funereoides Steyaert } & Camellia sinensis (L.) Kunteze, & Fatehi \& Mirhosseini-Moghadam \\
\hline & Cedrus deodora (Rob. ex Lambert) & 1993, Borhani \& Moussazadeh \\
\hline & Don, Cupressus arizonica Greene, $C$. & 2004, Borhani et al. 2006, Ershad \\
\hline & sempervirens L., C. sempervirens & 1995, Khabiri 1952, Scharif \& \\
\hline & $\begin{array}{l}\text { var. horizantalis (Mill.) Gord, Picea } \\
\text { abies Degen, Prunus sp., Sequoia } \\
\text { semepervirens Endl. }\end{array}$ & Ershad 1966 \\
\hline \multirow[t]{4}{*}{-guepinii (Desm.) Steyaert } & Cyperus rotundus $\mathrm{L}$. & Farzaneh et al. 2006, Aghajani et \\
\hline & Camellia sinensis $(\mathrm{L})$. & al. 2010 \\
\hline & Parrotia persica L. & Fatehi \& Mirhosseini-Moghadam \\
\hline & $\begin{array}{l}\text { Peterocaria fraxinifolia } \mathrm{L} . \\
\text { Juglans regia } \mathrm{L} \text {. }\end{array}$ & 1993 \\
\hline -longiseta (Speg.) K. Dai \& Ts. & Actinidia chinensis Planch., Camellia & Mousakhah et al. 2008, Fatehi \& \\
\hline Kobay. & sinensis (L.) Kunteze & $\begin{array}{l}\text { Mirhosseini-Moghadam } 1993 \\
\text { Khodaparast et al. } 1993\end{array}$ \\
\hline -longisetula Guba & Fragaria ananassa Duchense & Sharifi et al. 2008 \\
\hline -macrospora (Cesati) Steyaert & Corylus avellana $\mathrm{L}$. & Taherzadeh et al. 1998 \\
\hline -nattrassi Steyaert & Camellia sinensis (L.) Kunteze & $\begin{array}{l}\text { Khodaparast and Hedjaroude } \\
1994\end{array}$ \\
\hline -neglecta (Thümen) Steyaert & Euonymus japonicas L., Rock & $\begin{array}{l}\text { Petrak 1956, Scharif \& Ershad } \\
\text { 1966, This study }\end{array}$ \\
\hline - smilacis (Schweinitz) Sutton & Smilax sp. & Khodaparast \& Hedjaroude 1995 \\
\hline -theae (Sawada) Steyaert & Camellia sinensis (L.) Kunteze & $\begin{array}{l}\text { Esfandiari 1947, 1948, Scharif \& } \\
\text { Ershad 1966, Viennot-Bourgin } \\
1976\end{array}$ \\
\hline -uvicola (Speg.) Bissett & Vitis vinifera $\mathrm{L}$. & ershad 1995 \\
\hline -sp. & Rosa sp. & Mirabolfathy \& Ershad 2004 \\
\hline Seimatosporium & Amygdalus communis L., Malus & Ershad 2009, \\
\hline $\begin{array}{l}\text { - fusisporum H.J. Swart \& D.A. } \\
\text { Griffiths }\end{array}$ & $\begin{array}{l}\text { pumila } \mathrm{L} ., \text { Pistacia vera } \mathrm{L} ., \text { Punica } \\
\text { granatum L., Pyrus communis L., } \\
\text { Rosa damascene L., Salix sp., Vitis } \\
\text { vinifera } \mathrm{L} .\end{array}$ & Aminaee \& Ershad 2008 \\
\hline - lonicerae (Cooke) Shoemaker & Vitis sylvestris Gmel. & Gräfenhan 2006 \\
\hline $\begin{array}{l}\text {-lichenicola (Corda) Shoemaker } \\
\text { \& Müll }\end{array}$ & Eucalyptus sp. & Aghapour et al. 2010 \\
\hline - sp. & Vitis sylvestris Gmel. & Grafenhan 2006 \\
\hline $\begin{array}{l}\text { Truncatella } \\
\text {-angustata (Pers.) Hughes }\end{array}$ & Olea europaea $\mathrm{L}$. & Arzanlou et al. 2012 \\
\hline
\end{tabular}

mounted in sterile distilled water or lactic acid were used for microscopic examinations. Dimensions of microscopic structures were calculated based on 30 measurements for conidial morphology (shape, colour, and cell number), size (length and width), and the presence and size of apical and basal appendages where possible. Photographs were captured on an Olympus digital camera system DP21 (Olympus Corporation, Japan) attached to a BX 41 Olympus microscope.

\section{DNA phylogeny}

The isolates were grown on MEA for 10 days in dark and genomic DNA was extracted using the protocol of Moller et al. 
(1992). The primers ITS1 and ITS4 (White et al. 1990) were used to amplify part of the nuclear rRNA operon spanning the 3' end of the $18 \mathrm{~S}$ rRNA gene, the first internal transcribed spacer (ITS1), the 5.8S rRNA gene, the second ITS region and the 5' end of the $28 \mathrm{~S}$ rRNA gene. The reaction mixture and PCR conditions followed Arzanlou \& Khodaei (2012a,b) and Arzanlou et al. (2012). The reaction was performed on a GeneAmp PCR System 9700 (Applied Biosystems, Foster City, CA) with cycling conditions consisting of 5 $\min$ at $96{ }^{\circ} \mathrm{C}$ for primary denaturation, followed by 40 cycles of $94^{\circ} \mathrm{C}$ for $30 \mathrm{~s}, 52^{\circ} \mathrm{C}$ for $30 \mathrm{~s}, 72^{\circ} \mathrm{C}$ for $60 \mathrm{~s}$, with a final extension at $72{ }^{\circ} \mathrm{C}$ for $7 \mathrm{~min}$. The obtained sequences were compared to the sequences available in NCBI's GenBank nucleotide (nr) database using a megablast search.

\section{Results}

A list containing four pestalotioid genera comprising 20 species is given in Table 1. The genus Pestalotiopsis with 12 species, which have been collected from 22 plant species, represents the highest number of pestalotioid fungi in Iran. For the genera Monochaetia and Seimatosporium only three species for each and for the genus Truncatella only a single species have been reported from Iran.

\section{Bartalinia pondoensis Marincowitz,} Gryzenhout \& Wingfield, Mycotaxon 111: 312, 2010.

Figs 1-6

Colonies on PDA fast growing, attaining a diam of $52 \mathrm{~mm}$ after 7 days in dark at room temperature, circular, with entire edge, olivaceous grey, with greyish white margin, covered with dense aerial mycelium. Mycelium immersed and superficial. Conidiomata pycnidial, immersed, globose, subglobose or ellipsoidal, $200-225 \times 200-260 \mu \mathrm{m}$, ostiolate, unilocular, scattered over the whole colony surface. Conidiophores reduced to conidiogenous cells. Conidiogenous cells discrete, ampulliform to lageniform, hyaline, smooth, formed from the inner cells of the pycnidial wall, 4-7 $\mu \mathrm{m}$ long, Conidia fusiform, straight or slightly bent, predominantly 3-4euseptate, with no constrictions at septa, 20-25 $\times 3-4 \mu \mathrm{m}$, with basal and apical appendages, the penultimate basal cell longer than the rest, hyaline or slightly pigmented, 2-4 $\mu \mathrm{m}$ long, 2 median cells cylindrical, thick-walled, pigmented, 16-19 $\mu \mathrm{m}$ long (the second cell from the base $8-11 \mu \mathrm{m}$ long, the third cell from the base 5-9 $\mu \mathrm{m}$ long, apical cell conic, hyaline, $2-3 \mu \mathrm{m}$ long, with a short tube $(0.5-1$ $\mu \mathrm{m}$ long) at the tip where branched appendages are attached; apical appendage with 2-3 branches attenuated toward tip, flexuous, (9-) 12-16 (-20) $\mu \mathrm{m}$ long; basal appendage single, filiform, exogenous, 2-6 $\mu \mathrm{m}$ long.

Material examined - IRAN, Bushehr Province, Kangan, Assaluyeh, on stems of Bambusa sp. (Poaceae), 10 June 2009. Living culture CCTU 459.

The ITS sequence data showed $100 \%$ homology with the sequence data for Bartalinia pondoensis in GenBank. The sequence is available in GenBank with the accession number JX854540.

Pestalotiopsis neglecta (Thümen) Steyaert, Transaction of the British Mycological Society 36: 83, 1953.

Figs 7-11

Colonies on PDA, fast growing, attaining a diam of $85 \mathrm{~mm}$ after 7 days in dark at room temperature, circular, with entire edge, non-zonate. Conidiomata acervular, black, covered with black, slimy conidial masses protruding from the surface. Conidiophores hyaline and branched. Conidiogenous cells annellidic, hyaline and smooth. Conidia fusiform or narrow fusiform, straight or slightly curved with a tapering base, five-celled with three colored median cells, the upper two cells being brown to yellow brown and the lowest cell being olivaceous. Conidia always smooth, up to $27 \mu \mathrm{m}$ long and $9 \mu \mathrm{m}$ wide, with a rounded apical end. The apical and basal cells hyaline, cylindrical to conic; median cells dark brown, with the two upper ones sometimes darker. Three to four apical (usually three) appendages up to $27 \mu \mathrm{m}$ long and one simple basal appendage $7 \mu \mathrm{m}$ long.

Specimen examined - Iran, Guilan Province, Talesh, rock sample, July 2010. Living culture CCTU 12. The ITS sequence data was deposited in to GenBank with the accession number JX854541. 

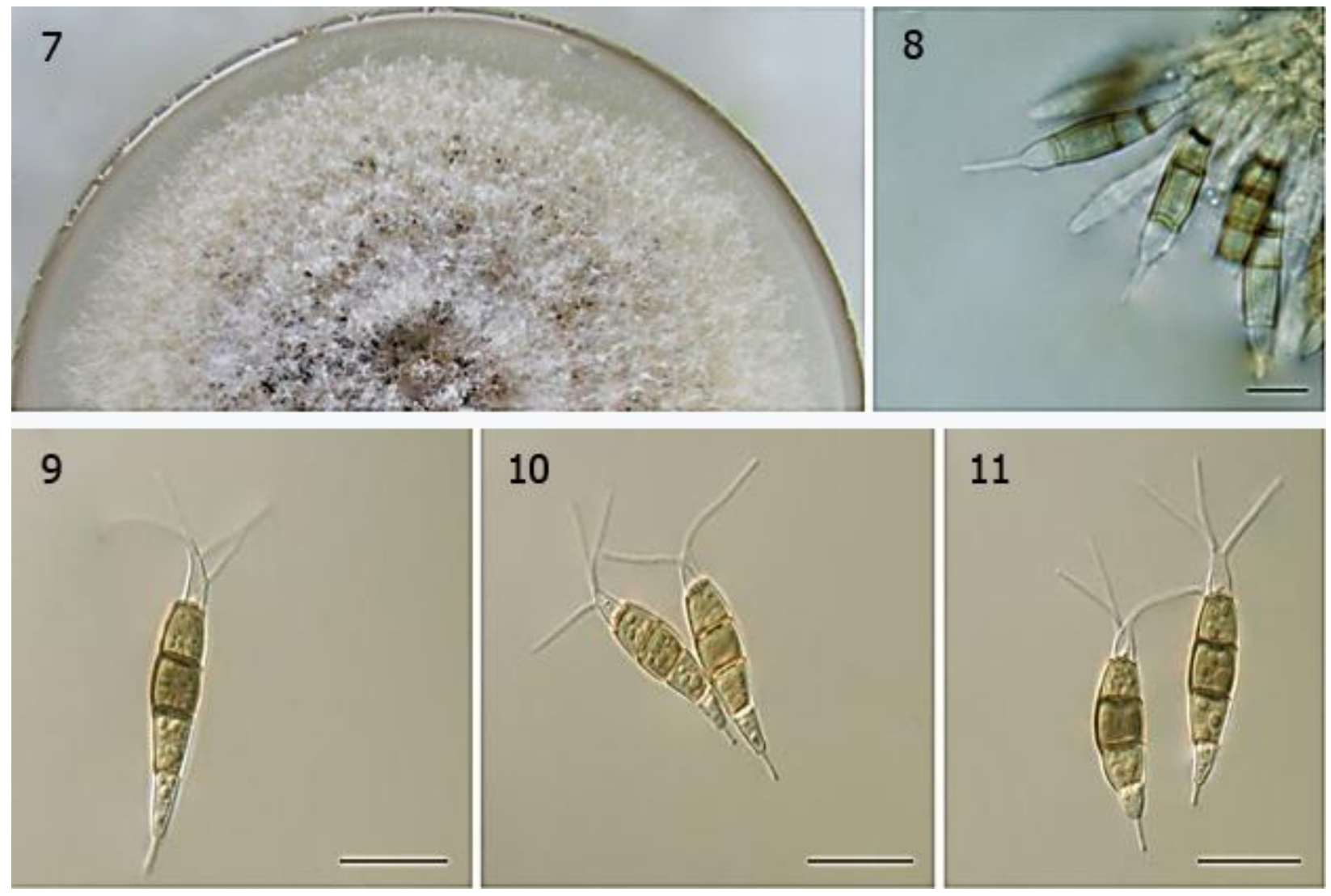

Figs 7-11 - Pestalotiopsis neglecta. 7 Colony morphology on PDA. 8 Conidia and conidiogenous cells. 9-11 Conidia. - Scale bars $=10 \mu \mathrm{m}$.

\section{Discussion}

The short check list of pestalotioid fungi provided in this paper highlights the paucity of knowledge on the diversity of pestalotioid fungi in Iran. A search of MycoBank 2012; www.mycobank.org) revealed 258 names for Pestalotiopsis, 127 names for Monochaetia, 78 names for Seimatosporium and 23 names for Truncatella. The genus Pestalotiopsis is the most commonly encountered pestalotioid fungus in Iran with only 12 species occurring on 22 plant species. Many of the pestalotioid species represent important plant pathogens; while, some are well known for their secondary metabolites used in pharmaceutical industry (Aly et al. 2010, Xu et al. 2010). Hence, there is an urgent need to explore biodiversity of pestalotioid genera in Iran.

With this paper we have described Bartalinia pondoensis as a new record for Iran from a Bambusa sp. based on morphological and molecular data. The morphology of our isolates was in full agreement with the description provided by Marincowitz et al. (2010). We also characterized Pestalotiopsis neglecta from a rock sample in northern Iran. The morphological and molecular data clearly fit with the description of Pestalotiopsis neglecta.

We hope that this work will stimulate other researchers to study the diversity of pestalotioid fungi in Iran.

\section{Acknowledgements}

The authors are grateful to the Research Deputy of the University of Tabriz and the Studienstiftung Mykologie for financial support.

\section{References}

Aghajani MA, Maleki Ziarati H, Aghapour B. 2010 - Report of new hosts for Pestalotiopsis guepinii in Iran. Proceedings of the $19^{\text {th }}$ Iranian Plant Protection Congress, vol II, 31 Jul.-3 Aug., Tehran, Iran: 33.

Aghapour B, Ahmadpour A, Fotouhifar KhB. 2010 - Seimatosporium lichenicola in Iran. Proceedings of the 19th Iranian Plant Protection Congress, vol II, 31 Jul.-3 Aug., Tehran, Iran: 40. 
Aly AH, Debbab A, Kjer J, Proksch P. 2010 Fungal endophytes from higher plants: a prolific source of phytochemicals and other bioactive natural products. Fungal Diversity 41, 1-16.

Aminaee MM, Ershad D. 2008 - First report of Seimatosporium fusisporum from Iran. Rostaniha 9 (1): 125-127 (in Persian) \& 61 (in English).

Arzanlou M, Khodaei S. 2012a - Phenotypic and molecular characterization of Chaetopyrena penicillata from Iran with description of a hyphomycete synanamorph. Mycosphere 3, 73-77.

Arzanlou M, Khodaei S. 2012b - Bipolaris spicifera isolates with unusual conidial germination pattern on sunflower from Iran. Plant Pathology \& Quarantine 2, 64-68.

Arzanlou M, Torbati M, Jafary H. 2012 - Fruit rot of olive (Olea europaea) caused by Truncatella angustata. Plant Pathology \& Quarantine 2, 117-123.

Barber PA, Crous PW, Groenewald JZ, Pascoe IG, Keane P. 2011 - Reassessing Vermisporium (Amphisphaeriaceae), a genus of foliar pathogens of eucalypts. Persoonia 27, 90-118.

Barr ME. 1975 - Pestalosphaeria, a new genus in the Amphisphaeriaceae. Mycologia 67, 187-194.

Barr ME. 1990 - Prodromus to nonlichenized, pyrenomycetous members of class Hymenoascomycetes. Mycotaxon 39, 43-184.

Borhani A, Moussazadeh S. 2004 - Study on the hosts and pathogenicity of Pestalotiopsis funerea (Desm.) Steyaert on some soft wood species in Mazenderan Province. Proceedings of the $16^{\text {th }}$ Iranian Plant Protection Congress, vol II, 28 Aug.-1 Sep., Tabriz, Iran: 441.

Borhani A, Khorankeh S, Alimosazadeh S. 2006 - Etiology and rate of die back on Pieca abies in Toska Cheshmaeh forestation area (Galogah-Mazenderan). Proceedings of the $17^{\text {th }}$ Iranian Plant Protection Congress, vol. II, 2-5 Sept., Karaj, Iran: 396.

De Hoog GS, Guarru J, Gene J, Figueras MJ. 2000 - Atlas of Clinical fungi.
Centralbureau voor Schimmel cultures, $1126 \mathrm{p}$.

Ershad D, 1995 - Fungi of Iran. Ministry of Agriculture, Agricultural Research, Education and Extension Organization. No $10,847 \mathrm{p}$.

Ershad D. 2009 - Fungi of Iran. 3rd edition, Iranian Research Institution of Plant Protection, $531 \mathrm{p}$.

Esfandiari E. 1947 - Les maladies des plantes cultivées et des arbres fruitiers des regions subtropicales du nord de I' Iran. Applied Entomology and Phytopathology $5,1-21$

Esfandiari E. 1948 - Troisième liste des fungi ramassés en Iran. Applied Entomology and Phytopathology 8, 1-15.

Espinoza JG, Briceño EX, Keith LM, Latorre BA. 2008 - Canker and twig dieback of blueberry caused by Pestalotiopsis spp. and a Truncatella sp. in Chile. Plant Disease 92, 1407-1414.

Farzaneh M, Javan-Nikkhah M, Fotoohifar KB, Karimmojeeni H. 2006 - First report of pathogenic Coelomycetes on Cyperus rotundus and Xanthium strumarium, from Iran. Proceedings of the $17^{\text {th }}$ Iranian Plant Protection Congress, vol. II, 2-5 Sept., Karaj, Iran: 423.

Fatehi J, Mirhosseini-Moghadam SA. 1993 Pestalotiopsis species on tea in Iran. Proceedings of the $11^{\text {th }}$ Iranian Plant Protection Congress, 28 Aug.-2 Sept., Karaj, Iran: 170.

Gräfenhan T. 2006 - Epidemiologie und biologische Bekämpfung latenter Rebholzkrankheite. Dissertation, Landwirtschaftlich-Gärtnerische Fakultät der Humboldt-Universität zu Berlin, 138 p.

Jeewon R, Liew ECY, Hyde KD. 2002 Phylogenetic relationships of Pestalotiopsis and allied genera inferred from ribosomal DNA sequences and morphological characters. Molecular Phylogenetics and Evolution 25, 378392.

Jeewon R, Liew ECY, Simpson JA, Hodgkiss IJ, Hyde KD. 2003 - Phylogenetic significance of morphological characters in the taxonomy of Pestalotiopsis 
species. Molecular Phylogenetics and Evolution 27, 372-383.

Jeewon R, Liew ECY, Hyde KD. 2004 Phylogenetic evaluation of species nomenclature of Pestalotiopsis in relation to host association. Fungal Diversity 17, $39-55$.

Kang JC, Kong RYC, Hyde KD. 1998 Studies on the Amphisphaeriales. 1. Amphisphaeriaceae (sensu stricto) and its phylogenetic relationships inferred from 5.8 S rDNA and ITS2 sequences. Fungal Diversity 1, 147-157.

Kang JC, Hyde KD, Kong RYC. 1999 Studies on Amphisphaeriales: the Amphisphaeriaceae (sensu stricto). Mycological Research 103, 53-64.

Khabiri E. 1952 - Contribution a la mycoflore de 1 Iran .Premiere liste, Revue Mycologique 17, 154-157.

Khodaparast SA, Hedjaroude GhA. 1994 Incidence of a new Pestalotiopsis species in association with grey blight of tea in Gilan. Iran. J. Plant Path. 30:79-80 (in Persian) \&33 (in English).

Khodaparast SA, Hedjaroude GhA. 1995 Occurrence of Pestalotiopsis smilacis (Schw.) Sutton in Iran. Proceedings of the $12^{\text {th }}$ Iranian Plant Protection Congress. 2-7 Sept., Karaj, Iran: 367.

Khodaparast SA, Hedjaroude GhA, Zad J, Eshpahri F, Okhovat M. 1993 - Studies on fungi isolated from tea in Iran. Proceedings of $11^{\text {th }}$ Iranian Plant Protection Congress. 28 Aug.-2 Sept., Rasht, Iran: 171.

Lee S, Crous PW, Wingfield MJ. 2006 Pestalotioid fungi from Restionaceae in the Cape Floral Kingdom. Studies in Mycology 55, 175-187.

Liu AR, Wu XP, Xu T, Guo LD, Wei JG. 2006 - Notes on endophytic Pestalotiopsis from Hainan, China. Mycosystema 25, 389-397.

Liu L, Tian RR, Liu SC, Chen XL, Guo LD, Che YS. 2008 - Pestaloficiols A-E, bioactive cyclopropane derivatives from the plant endophytic fungus Pestalotiopsis fici. Bioorganic and Medicinal Cemistry 16, 6021-6026.

Marincowitz S, Gryzenhout M, Wingfield MJ. 2010 - New and rare coelomycetes with appendage-bearing conidia from Pondoland, South Africa. Mycotaxon 111, 309-322.

Mirabolfathy M, Ershad D. 2004 - Twig and cane canker of rose in the greenhouse of central area of Iran. Iranian Journal of Plant Pathology 40, 347-348 (in Persian) \& 84-85 (in English).

Moller EM, Bahnweg G, Geiger HH. 1992 - A simple and efficient protocol for isolation of high molecular weight DNA from filamentous fungi, fruit bodies, and infected plant tissues. Nuclear Acid Research 20, 6115-6116.

Mousakhah M, Rajabi R, Amirkiali Gh, Barari A, Nick M. 2008 - First report of Pestalotiopsis longiseta, the associated fungus with Kiwi leaf spot in Gilan. Proceedings of the $18^{\text {th }}$ Iranian Plant Protection Congress, vol. II, 24-27 Aug., Hamedan, Iran: 57.

Petrak F. 1956 - Iranische Pilze. Sydowia 10, $1-17$.

Roohibakhsh A, Ershad D. 1997 - An investigation on mycoflora of citrus necrotic leaf spots in western part of Mazenderan. Iranian Journal of Plant Pathology 33, 94-110 (in Persian) \& 3437 (in English).

Scharif G, Ershad D. 1966 - List of fungi cultivated plants, shrubs and trees of Iran. Ministry of Agriculture, Plant Pests and Diseases Research Institute, Evin, Tehran.

Sharifi K, Javadi-Estabanati AR, Mahdavi M. 2008 - A new Pestaloiopsis species for the mycoflora of Iran. Rostaniha 9(2): 260 (in Persian) \& 118 (in English).

Sutton DA. 1999 - Coelomycetous fungi in human disease. A review: clinical entities, pathogenesis, identification and therapy. Revista Iberoamericana de Micologia 16, 171-179.

Taherzadeh M, Mir Hosseini-Moghaddam SA, Ershad D, Zakiei Z, Elahinia SA. 1998 Isolation of the fungi from hazelnut and their loss and economic importance. Proceedings of the $13^{\text {th }}$ Iranian Plant Protection Congress, vol. II, 23-27 Aug., Karaj, Iran: 229.

Tanaka K, Endo M, Hirayama K, Okane I, Hosoya T, Sato T. 2011 - Phylogeny of 
Discosia and Seimatosporium, and introduction of Adisciso and Immersidiscosia genera nova. Persoonia 26, 85-98.

Tejesvi MV, Tamhankar SA, Kini KR, Rao VS, Prakash HS. 2009 - Phylogenetic analysis of endophytic Pestalotiopsis species from ethnopharmaceutically important medicinal trees. Fungal Diversity 38, 167-183.

Viennot-Bourgin G. 1976 - Personal communication. Ministre de I Agricuture, Institut National Agronomique, Laboratoire de Botanique et Pathologic Végétale, Paris, France.

Watanabe K, Motohashi K, Ono Y. 2010 Description of Pestalotiopsis pallidotheae: a new species from Japan. Mycoscience 51, 182-188.

Wei JG, Xu T, Guo LD, Pan XH. 2005 Endophytic Pestalotiopsis species from southern China. Mycosystema 24, 481493.

Wei JG, Xu T, Guo LD, Liu AR, Zhang Y, Pan XH. 2007 - Endophytic Pestalotiopsis species associated with plants of Podocarpaceae, Theaceae and Taxaceae in southern China. Fungal Diversity 24, 5574.

White TJ, Bruns TD, Lee SB, Taylor JW. 1990 - Amplification and sequencing of fungal ribosomal RNA genes for phylogenetics. In: PCR-Protocols and Applications - A Laboratory Manual (eds N Innis, D Gelfand, J Sninsky, TC White). Academic Press, New York, 315-322.

Xu J, Ebada SS, Proksch P. 2010 Pestalotiopsis a highly creative genus: chemistry and bioactivity of secondary metabolites. Fungal Diversity 44, 15-31. 